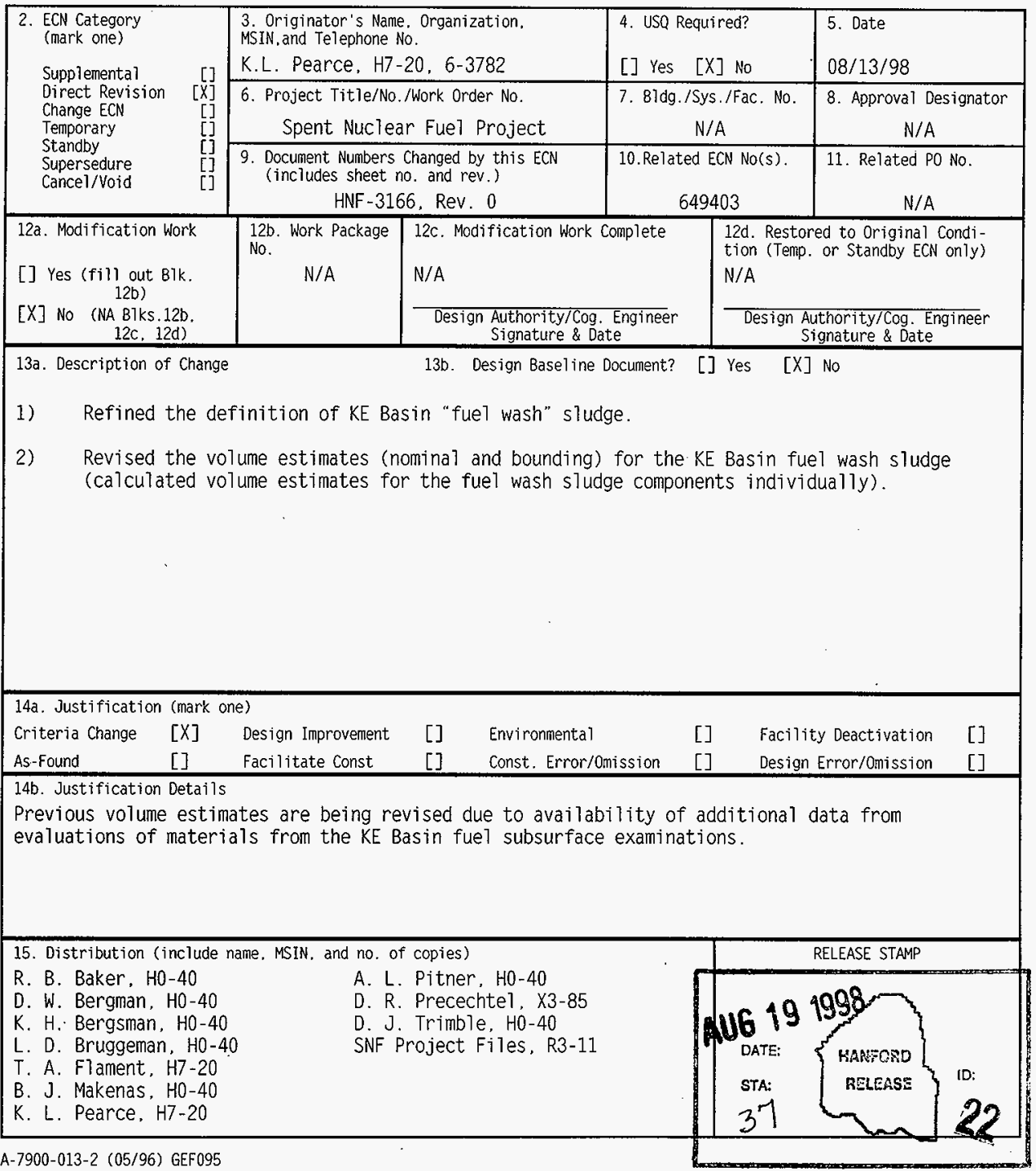


16. Design

Verification

Required

[] Yes

$[X]$ No
17. Cost Impact

ENGINEERING

Additional [NA] \$

Savings

[NA] \$

CONSTRUCTION

$\begin{array}{lll}\text { Additionai } & {[N A]} & \$ \\ \text { Savings } & {[N A]} & \$\end{array}$

18. Schedule Impact (days)

Improvement

Delay
[NA]

[NA]

19. Change Impact Review: Indicate the related documents (other than the engineering documents identified on Side 1) that will be affected by the change described in Block 13 . Enter the affected document number in Block 20 .

$\begin{array}{ll}\text { SOD/DO } & {[]} \\ \text { Functional Design Criteria } & {[]} \\ \text { Operating Specification } & {[]} \\ \text { Criticality Specification } & {[]} \\ \text { Conceptual Design Report } & {[]} \\ \text { Equipment Spec. } & {[]} \\ \text { Const. Spec. } & {[]} \\ \text { Procurement Spec. } & {[]} \\ \text { Vendor Infornation } & {[]} \\ \text { OM Manual } & {[]} \\ \text { FSAR/SAR } & {[]} \\ \text { Safety Equipment List } & {[]} \\ \text { Radiation work Permit } & {[]} \\ \text { Environnental Impact Statement } & {[]} \\ \text { Enviromental Report } & {[]} \\ \text { Environmental Permit } & {[]}\end{array}$

[] Seismic/Stress Analysis

[]

Tank Calibration Hanual

[] Stress/Design Report

[] . Interface Control Orawing

[]

[]

[] Caibration Procefure

[]

[] Installation Procedure

[]

Maintenance Procedure

[]

Engineering Procedure

[]

Operating Instruction

[]

Operating Procedure

[]

Operational Safety Requirement

[]

IEFO Orawing

[]

Cell Arrangement Drawing

[]

Essential Material Specification

[]

Fac. Proc. Samp. Schedule

[]

Heaith Physics Procedure

Spares Multiple Unit Listing

Test Procedures/Specification

Component Index

ASME coded Item

Human factor Consideration

Computer Software

Electric Circuit Schedule

ICRS Procedure

Inspection Plan

[]

Process Control Manual/Plan

Process flow Chart

Purchase Requisition

Inventory Adjustment Request

[]

rickler file

20. Other Affected Documents: (NOTE: Documents listed below will not be revised by this ECN.) Signatures below indicate that the signing organization has been notified of other affected documents listed below.

Document Number/Revision

Document Number/Revision

Document Number Revision

HNF-SD-SNF-TI-053, Rev. 0

\section{Approvals}

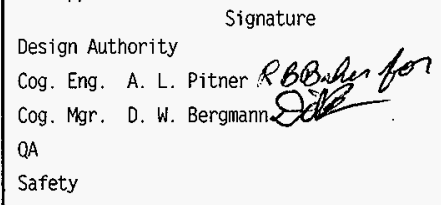

Environ.

other K. L. Pearce Py Patee

Date
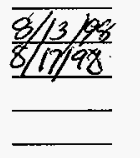

$8 / 13 / 98$
Signature

Date
Design Agent

$P E$

QA

Safety

Design

Environ.

Other

\section{DEPARTMENT OF ENERGY}

Signature or a Control Number that tracks the Approval Signature

ADDITIONAL 


\title{
K EAST BASIN SLUDGE VOLUME ESTIMATES FOR INTEGRATED WATER TREATMENT SYSTEM
}

\author{
"K. L. Pearce and A. L. Pitner
}

Duke Engineering \& Services Hanford, Inc., Richland, WA 99352

U.S. Department of Energy Contract DE-AC06-96RL13200

EDT/ECN: 649402

Org Code: 2 T960

B\&R Code: EW7040000
UC: UC 2070

Charge Code: LB030

Total Pages: 10

Key Words: Sludge, KE Basin, fuel condition, fuel storage, fuel processing

Abstract: This document provides estimates of the volume of sludge 1)expected from Integrated Process Strategy (IPS) processing of the fuel elements and 2) in the fuel storage canisters in $\mathrm{K}$ East Basin. The original estimates were based on visual observations of fuel element condition in the basin and laboratory measurements of canister sludge density. Revision 1 revised the volume estimates of sludge from processing of the fuel elements based on additional data from evaluations of material from the KE Basin fuel subsurface examinations. A nominal "Working Estimate" and an upper level "Working Bound" is developed for the canister sludge and the fuel wash sludge components in the KE Basin.

"Numatec Hanford Company, Richland, Washington.

TRADEMARK DISCLAIMER. Reference herein to any specific commercial product, process, or service by trade name, trademark. manufacturer, or otherwise, does not necessarily constitute or imply its endorsement, recommendation, or favoring by the United States Government or any agency thereof or its contractors or subcontractors.

Printed in the United States of America. To obtain copies of this document. contact: Document Control Services, P.0. Box 950. Mailstop H6-08. Richland WA 99352. Phone (509) 3722420; Fax (509) 376-4989.

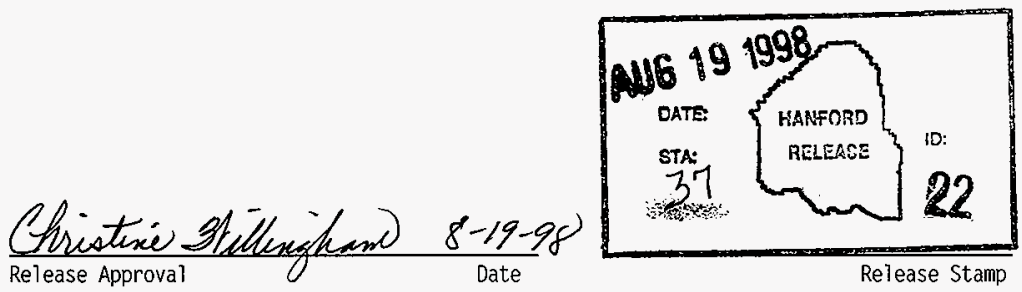


(2) Title

$K$ EAST BASIN SLUDGE VOLUME ESTIMATES FOR INTEGRATED WATER TREATMENT SYSTEM

CHANGE CONTROL RECORD

\begin{tabular}{|c|c|c|c|}
\hline \multirow{2}{*}{ (3) Revision } & \multirow{2}{*}{ (4) Description of Change - Replace, Add, and Delete Pages } & \multicolumn{2}{|c|}{ Authorized for Release } \\
\hline & & (5) Cog. Engr. & (6) Cog. Mgr. \\
\hline 0 & $\begin{array}{l}\text { (7) Initial Release EDT } 620807 \text {, dated } \\
08 / 12 / 98\end{array}$ & A. L. Pitner & D. W. Bergmann \\
\hline${ }^{1} R$ & $\begin{array}{l}\text { ECN } 649402 \text { - Revised KE Basin fuel wash } \\
\text { sTudge estimates. Replace all pages. }\end{array}$ & $\begin{array}{l}\text { A.L. Pitneg } \\
\text { KePfor A L.Pither }\end{array}$ & D. \\
\hline & & & \\
\hline & & & \\
\hline & & & \\
\hline & & & \\
\hline & & & \\
\hline & & & \\
\hline & & & \\
\hline & & & \\
\hline & & & \\
\hline & & & \\
\hline & & & \\
\hline & & & \\
\hline & & & \\
\hline & & & \\
\hline & & & \\
\hline & & & \\
\hline & & & \\
\hline & & & \\
\hline & & & \\
\hline & & & \\
\hline & & & \\
\hline & & & \\
\hline & & & \\
\hline
\end{tabular}


HNF-3166, Rev. 1

\section{K EAST BASIN SLUDGE VOLUME ESTIMATES FOR INTEGRATED WATER TREATMENT SYSTEM}

August 1998

Originators:

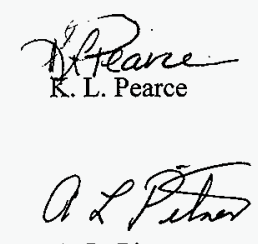

A. L. Pitner

Peer Review:

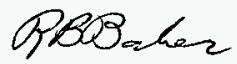

R. B. Baker

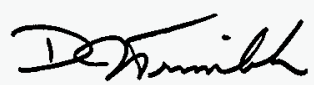

D. J. Trimble 


\subsection{PURPOSE AND SCOPE}

The purpose of this document is to provide an estimate of the volume of sludge expected from Integrated Process Strategy (IPS) processing of the KE Basin fuel storage canisters to support the Integrated Water Treatment System (IWTS), the Sludge Retrieval System (SRS) and the Sludge Treatment System. The previous volume estimates were based on visual observations of fuel condition and laboratory measurements of $\mathrm{KE}$ canister sludge density. The previous estimates are being revised based on the availability of additional data from evaluations of material from the $\mathrm{K}$ Basin fuel subsurface examinations (Pitner 1997 and Silvers 1998). Additionally, it was previously assumed that fuel wash sludge was generated by fuel metal pieces being granulated in the fuel wash machine and turned into sludge. This definition has been refined as the wash machine does not have the capability to significantly "granulate" the fuel pieces. However, it is expected that the washing process will cause further breakage of the elements and dislodge corroded uranium pieces, zirconium cladding, and loosely adhered material (such as coatings and internal sludge). This dislodged material is referred to as the fuel wash sludge and is assumed comprised of three components; coating, fuel pieces and internal sludge (i.e., sludge originating from within the fuel elements). During IWTS processing, the fuel wash sludge components will be separated into two feed streams based on particle size. Because the fuel subsurface examinations indicate the materials (coatings, internal sludge and fuel pieces) have a range of particle sizes, a volume is calculated for each fuel wash sludge component rather than a total volume for the wash sludge as a whole as was done in the previous volume estimate for fuel wash sludge.

A nominal "Working Estimate" as well as an upper level "Working Bound" were developed for the canister sludge and each of the fuel wash sludge components in the KE Basin.

\subsection{RESULTS}

The Working Estimates of the sludge volumes for IWTS, SRS and Sludge Treatment design basis are 3,000 liters for canister sludge, 149 liters for fuel pieces, 518 liters for internal sludge and 61 liters for coating sludge. The Working Bound is 7,400 liters for canister sludge, 373 liters for fuel pieces, 1294 liters for internal sludge and 92 liters for coating sludge.

\subsection{ASSUMPTIONS AND ANALYSIS}

\subsection{KE CANISTER SLUDGE}

Based on ultrasonic measurements of sludge depths in selected KE Basin canisters (Pitner 1996a), the "Working Estimate" of canister sludge volume is 3,000 liters. For the "Working Bound," the two sigma uncertainties of the measurements were used to calculate a value of 7,400 liters. 


\subsection{KE FUEL WASH SLUDGE}

Experimental tests on the cleaning process have not been done; therefore, no samples of actual $\mathrm{KE}$ Basin fuel wash sludge components exist. However, examinations were made of the surface and/or subsurface of a KE Basin fuel element. The examinations included collection of coating pieces from the fuel cladding and particles recovered from the cracks in the fuel and from beneath the cladding material. Often the particulate material was accompanied by large $(0.64$ to $1.27 \mathrm{~cm}$ [0.25- to 0.5 -in.]) pieces of fuel. In general, no great quantities of sludge or particulate fuel were found beneath the cladding breaches. However, substantial residue sample was obtained by straining the water from the spent fuel element container (SFEC [used to transport the fuel element to the 300 Area hot cells]), suggesting that loose fuel material escaped from breached areas during shipping and handling activities (Pitner 1997). The subsurface particles from the fuel elements and the residue from the SFEC make up the internal sludge. Data from the examinations of the coating, internal sludge and fuel pieces form the basis of the volume estimates (Pitner 1997, and Silvers 1998).

\subsubsection{Assumptions}

The following list of assumptions apply in the derivation of a volume estimate for the fuel wash sludge:

- In KE Basin, there are approximately 1,100 MTU of fuel contained in 50,577 fuel assemblies (Pajunen 1996).

- $\quad$ Most of the "Bad" fuel that will be lost during cleaning comes from the outer elements in the form of fuel pieces and internal sludge. This is based on visual observations (Pitner 1996b) and results from the K Basin fuel subsurface examinations (Pitner 1997). The outer elements have a volume of about 1 liter each. The quantities of fuel pieces and internal sludge due to the inner element are negligible compared to the amount due to the outer element.

- The fraction of fuel in the "Bad" category is 4\% (Pitner 1996b). Based on visual observations of fuel and sludge loss during the recent "lift and look" examinations in the $\mathrm{KE} \mathrm{Basin}$, it is projected that, on the average, $10 \%$ of the outer element fuel volume would be lost during cleaning as a "Working Estimate." For the "Working Bound," the corresponding value is estimated to be $25 \%$.

- The fraction of fuel assemblies that are in the "Defected" category is $38 \%$ (Pitner 1996b). For the "Working Estimate," an average of $2 \mathrm{~cm}^{3}$ (0.002 liter) of internal sludge would likely be displaced from assemblies in this category during cleaning. For the "Working Bound," the corresponding value is $5 \mathrm{~cm}^{3}(0.005$ liter).

- The quantity of "gray" coating material recovered from surfaces of two KE fuel elements (KE Basin canisters $2350 \mathrm{E}$ and $2540 \mathrm{E}$ ) has been estimated as 0.55 $\mathrm{mg} / \mathrm{cm}^{2}$ (Marschman 1997). This value was based on the weight of coating recovered and an estimate of the scraped surface. All of the fuel elements have coating material on the surfaces. 
- Nominal dimensions of the fuel elements are:

Nominal outer element $=6.14 \mathrm{~cm}$ OD $\times 4.32 \mathrm{~cm} \mathrm{ID} \times 66.04 \mathrm{~cm}$ long

Nominal inner element $=3.25 \mathrm{~cm}$ OD x $1.22 \mathrm{~cm} \mathrm{ID} \times 66.04 \mathrm{~cm}$ long

- The efficiency of the washing machine in removing the coating from the cladding surface is assumed to be; $100 \%$ removed from the outside of the outer element, $50 \%$ removed from the inside of the outer element and outside of the inner element, and 0\% removed from the inner element for the "Working" estimate. For the "Bounding" estimate, it is assumed $100 \%$ of the coating is removed from the inside and outside of both inner and outer elements.

- The dry particle density of the internal sludge from "Bad" and "Defected" fuel elements is assumed to be a mean of dry density measurements (it is assumed the dry density used in the calculations refers to solids density or particle density, not "bulk" dry density) from samples of the residual in the SFEC obtained during the fuel subsurface examinations (Silvers 1998).

- Dry density measurements were performed on only one coating sample from a $\mathrm{KW}$ fuel element. The KE element coating dry density is assumed to be the same as that reported for the KW coating. Coating dry density is assumed to be a mean of the two dry density measurements obtained from coating sample CS4 (Silvers 1998). The mean dry density for coating is therefore, $2.06 \mathrm{~g} / \mathrm{cc}((2.04+2.07) / 2)$. The density for fuel pieces is assumed to be $19 \mathrm{~g} / \mathrm{cc}$.

- Final as-settled sludge volumes for the three components are based on assuming an as-settled density of $11 \mathrm{~g} / \mathrm{cc}$ for fuel pieces, $3 \mathrm{~g} / \mathrm{cc}$ for internal sludge and 1.48 $\mathrm{g} / \mathrm{cc}$ for coating. These assumptions are engineering judgements based on review of all the sludge and related density data.

- The quantities of material retrieved during the fuel subsurface examinations are summarized in Table 1 (Pitner 1997). 
HNF-3166, Rev. 1

Table 1. Fuel Element Material Recovery Data Related to Wash Sludge Components.

\begin{tabular}{|c|c|c|c|c|}
\hline Fuel Element Reference & $\begin{array}{l}\text { Subsurface Sludge } \\
\text { (g dry) }\end{array}$ & $\begin{array}{c}\text { SFEC Residue } \\
\text { (g dry) }\end{array}$ & $\begin{array}{l}\text { Fuel Pieces }^{(1)} \\
(\mathrm{g})\end{array}$ & $\begin{array}{l}\text { Sample } \\
\text { Reference }\end{array}$ \\
\hline \multirow{6}{*}{$\begin{array}{l}\text { 5427E } \\
\mathrm{KE} \text { "Bad" Category }\end{array}$} & & & 100.02 & FS1 \\
\hline & & 42.57 & & R1 \\
\hline & 15.53 & & & SSL1 \\
\hline & 15.53 & & $45.78^{(2)}$ & SSL2 \\
\hline & 4.78 & & $4^{(3)}$ & SSL3 \\
\hline & Total SS $=35.84$ & Total SFEC $=42.57$ & $\begin{array}{l}\text { Total FP }= \\
149.80\end{array}$ & \\
\hline \multirow{3}{*}{$\begin{array}{l}\text { 6743U } \\
\text { KW "Bad" Category }\end{array}$} & & 2.31 & & $\mathrm{R} 2$ \\
\hline & 4.42 & & & SSL4 \\
\hline & 1.68 & & & SSL5 \\
\hline \multirow{3}{*}{$\begin{array}{l}7913 \mathrm{U} \\
\mathrm{KW} \text { "Bad" Category }\end{array}$} & & 2.21 & & R3 \\
\hline & 3.75 & & $4^{(3)}$ & SSL7 \\
\hline & 8.19 & & & SSL8 \\
\hline Mean Sum of KW "Bad" & $\begin{array}{l}\text { Mean Total SS }=(6.1+ \\
{[1.94) / 2=9.02}\end{array}$ & $\begin{array}{l}\text { Mean Total SFEC }=(2.31+ \\
2.21) / 2=2.26\end{array}$ & Total FP $=4^{(4)}$ & \\
\hline
\end{tabular}

(1)Fuel Pieces are assumed to be "fuel particles" less than $1 / 4$ " in diameter. This results from the SNF Project operational definition of sludge (all material less than $1 / 4$ " in diameter).

(2) The amount of particulate in SSL2 is equivalent (visually) to SSL1, so 15.53 has been subtracted from the initial value reported (Pitner 1997).

${ }^{(3)}$ There is about $4 \mathrm{~g}$ (estimated) of fuel particles in SSL3 and SSL7

(4) Note: the total fuel mass was not averaged based on engineering judgement that the washing machine would generate at least the $4 \mathrm{~g}$ per element in the "Bad" category.

\subsubsection{Coating Material Mass}

The nominal quantity of coating from one fuel assembly is calculated as follows (top and bottom end-cap surface area is assumed to be insignificant):

Outer element $=0.55 *(6.14 * 1+4.32 * 0.5) * 3.14 * 66.04=947 \mathrm{mg}$ Inner element $=0.55 *(3.25 * 0.5+1.22 * 0) * 3.14 * 66.04=185 \mathrm{mg}$ Coating/fuel assembly $=0.947+0.185=1.13 \mathrm{~g}$ 
The bounding quantity of coating from one fuel assembly is calculated as follows:

Outer element $=0.55 *(6.14 * 1+4.32 * 1) * 3.14 * 66.04=1193 \mathrm{mg}$

Inner element $=0.55 *(3.25 * 1+1.22 * 1) * 3.14 * 66.04=510 \mathrm{mg}$

Coating/fuel assembly $=1.19+0.510=1.70 \mathrm{~g}$

\subsubsection{Percent Mix of "Bad" Fuel}

The percentages of fuel pieces and internal sludge (based on an average of $\mathrm{KE}$ and $\mathrm{KW}$ data) in the "Bad" fuel category are determined as follows:

Mass of Fuel Pieces $=(149.80+4) \mathrm{g} / 2=76.90 \mathrm{~g}$

Mass of internal sludge $=(35.84+42.57+9.02+2.26) \mathrm{g} / 2=44.85 \mathrm{~g}$

Dry Density of Internal Sludge (IS):

$\mathrm{R} 1-6$ mean density $=(7.98+8.04) / 2=8.01 \mathrm{~g} / \mathrm{mL}$

$\mathrm{R} 1-8$ mean density $=(7.99+8.02) / 2=8.01 \mathrm{~g} / \mathrm{mL}$

$\mathrm{R} 1-14$ mean density $=(8.01+7.99) / 2=8.00 \mathrm{~g} / \mathrm{mL}$

$\mathrm{R} 1-24$ mean density $=(8.00+7.97) / 2=7.99 \mathrm{~g} / \mathrm{mL}$

$\mathrm{R} 1-60$ mean density $=(7.85+7.84) / 2=7.85 \mathrm{~g} / \mathrm{mL}$

$\mathrm{R} 1-\mathrm{REC}+\mathrm{R} 1-\mathrm{REC}$ mean density $=(7.16+7.46) / 2=7.31 \mathrm{~g} / \mathrm{mL}$

IS density $=(.35 * 8.01+.04 * 8.00+.03 * 7.99+.06 * 7.85+.51 * 7.31)=7.56 \mathrm{~g} / \mathrm{mL}$

Volume Fuel Pieces $=76.90 \mathrm{~g} / 19 \mathrm{~g} / \mathrm{mL}=4.05 \mathrm{~mL}$

Volume IS $=44.85 \mathrm{~g} / 7.56 \mathrm{~g} / \mathrm{mL}=5.93 \mathrm{~mL}$

vol $\%$ fuel pieces $=41 \%$

vol $\%$ internal sludge $=59 \%$

\subsubsection{KE Fuel Wash Sludge Volume}

Using the assumptions stated above, as-settled sludge volumes for KE fuel wash sludge components were calculated. The nominal "Working Estimate" and the upper level "Working Bound" volume calculations for the KE fuel wash sludge components are shown on Tables 2 and 3 , respectively. 
Table 2. KE Fuel Wash Sludge Component Nominal Volume Estimates.

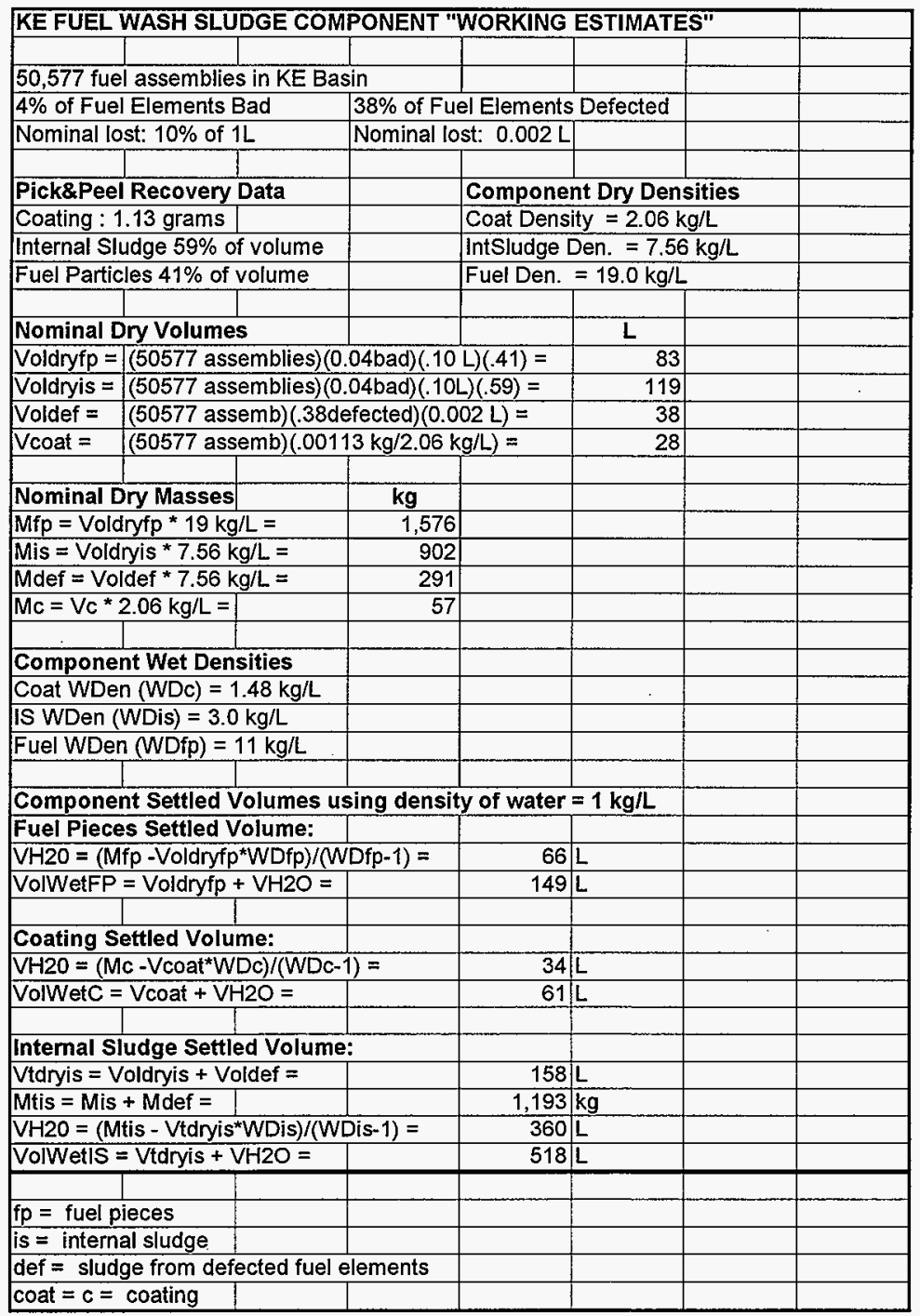


Table 3. KE Fuel Wash Sludge Components Bounding Volume Estimates.

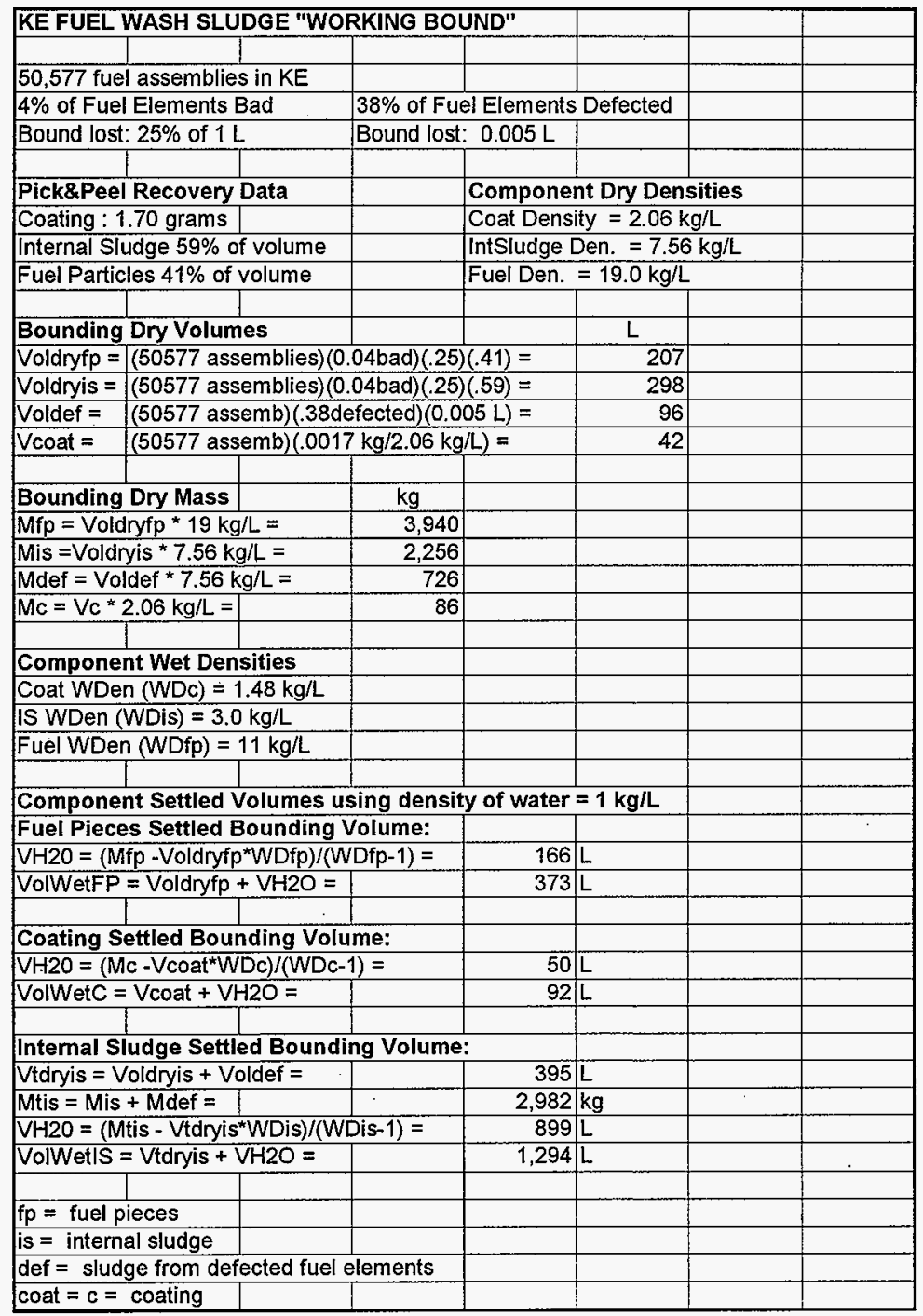


HNF-3166, Rev. 1

\subsection{REFERENCES}

Marschman, S.C., and J., Abrefah, 1997, "Highlight Report: Water Content of Film Coatings on K-East Fuel Surfaces," SNFCT97:040:R00, Pacific Northwest National Laboratory, Richland, Washington.

Pajunen, A. L., 1996, Development of Design Basis Capacity for SNF Project Systems, WHCSD-SNF-TI-016, Revision 0, Westinghouse Hanford Company, Richland, Washington.

Pitner, A. L., 1996a, K East Canister Sludge Survey, WHC-SD-SNF-TI-034, Rev. 0, Westinghouse Hanford Company, Richland, Washington.

Pitner, A. L., 1996b, K East Fuel Cleanliness Evaluation, WHC-SD-SNF-TI-018, Rev. 0, Westinghouse Hanford Company, Richland, Washington.

Pitner, A. L., 1997, K Basin Fuel Subsurface Examinations and Surface Coating Sampling, HNF-SD-SNF-TI-060, Rev. 0, Duke Engineering \& Services Hanford, Inc., Richland, Washington.

Silvers, K. L., 1998, (PNNL External Letter to R. P. Omberg [DESH], "K Basin Fuel Internal Sludge and Coating Evaluation", 28964-02), Pacific Northwest National Laboratory, Richland, Washington. 